IIUC STUDIES

ISSN 1813-7733

Vol.- 9, December 2011

(p 243-260)

\title{
Information Technology (IT) Ethics in the Light of Islam
}

\author{
Abdul Kadar Muhammad Masum* \\ Md. Cholem Ullah ${ }^{* *}$ \\ Md. Abul Kalam Azad ${ }^{* * *}$
}

\begin{abstract}
Globalization and digital convergence in the emerging knowledge society has raised complex ethical, legal and societal issues. We are faced with complex and difficult questions regarding the freedom of expression, access to information, the right to privacy, intellectual property rights, and cultural diversity. To overcome these issues, it requires qualified and educated IT (Information Technology) beneficiaries professionally and ethically. Professional organizations like ACM, IEEE and ABET have established codes of ethics to help IT professionals, specially end users to understand and manage their ethical responsibilities. Islamic ethics comprise moral principles and guidance that differentiate between right and wrong, which are comprehensive, stable, fair, and historically proved success in building ethically great societies. The estimated 1.5 billion of Muslims should have an effective role in IT related activities and life, which requires them to understand and implement ethics, specially the Islamic ethics in their IT related works. This paper is a roadmap for modeling the IT user principles, which show the main phases for solving such problems. It focuses mainly on adopting a new version of IT user principles based on Islamic ethical values.
\end{abstract}

Index Terms: Information Technology (IT), Ethics, Islamic Ethics, Principles.

\section{Introduction}

You are the best of peoples, evolved for mankind, enjoining what is right, forbidding what is wrong, and believing in Allah. (Qur'an 3:110)

\footnotetext{
* Assistant Professor, Department of Business Administration, IIUC.

** Lecturer, Center for University Requirement Courses (CENURC), IIUC.

*** Assistant Professor, Department of Business Administration, IIUC.
} 
We live in an era of superlative technological advances. We have reached a new height of development in our life. Information and communication technology is the overriding factor. Information technology (IT) has become all pervasive in the lives of millions all over the world. It has become an instrumental need of all humans to gather knowledge as well as information. A person can learn or garner anything he or she needs by clicking on the mouse of a personal computer with internet connectivity. Internet has ushered in a new dimension in our life.

But everybody in the Islamic world wants a guaranteed right in the ethics of using information technology. IT is frequently used illegally infringing its ethics all over the world. Its rights, which are already legally recognized, are being violated daily in the name of economic advancement, political stability, religious causes, campaigns against terrorism or for personal greed and interests. Violations of these rights have created new problems in human social systems, such as the digital divide, cybercrime, digital security and privacy concerns. All of those have affected people's lives either directly or indirectly. Such hitech advances sometimes deny the underlying IT ethical issues.

Though our information systems have evolved from data processing, through information systems, to artificial intelligence and embedded systems, there has not been sufficient advancement in dealing with the ethical issues these technologies have spawned [1]. Ogburn's cultural lag theory suggests that technology is advancing faster than the ethical infrastructure necessary to control and support these gains [2]. That's why, ethics are necessary to check IT-related abuses. So, Islamic ethics are, therefore, vital to expand the ethical research to help bridge the gap between behaviour and information science advances.

Even there are many people who take a chance to visit various stock market websites to easily identify them as bullish or bearish. Many are very intruder in nature. They secretly visit other people's personal files and data which is a total violation of Amanah in the light of Islam. This is totally unethical. Understanding unethical IT behavior can have tremendous returns. There are many recent examples of the impacts of unethical IT behavior, including problems such as software piracy, virus development and illegal access. Such unbecoming behavior cost a lot per year [3]. Many ethical issues have been identified as emerging from the tremendous growth of electronic commerce. 


\section{Objectives of the Study}

The foremost objective of the study is to incorporate Islamic ethics with conventional IT ethics. In addition, this paper will give intent look at;

1. To review the underlying concepts of ethic and Islamic ethics for IT related resources in a workstation.

2. To develop some principles for IT professionals including end users, especially the Muslims, both from Islamic and general perspectives.

3. To diagnose present challenges of IT ethics and to propose some suggestions to overcome the hindrances.

\section{Methodology of the Study}

This study is a desk-based and library-oriented research. To find out the development in IT ethics and related Islamic issues, the authors consulted available published literatures, research monograms, journals and magazines in the field of Information Technology. The secondary data are derived from both Islamic and conventional literatures in this regard. It is worth mentioning here that the Qur'an and Hadiths are used in this study as original and primary source of data for the respective theme and concept. Other relevant literatures are also studied and examined carefully to fulfill the defined objectives taken in the present study.

\section{Research Rationale}

The new media, which is an emerging mass media largely based on electronic communication, is critical to the field of Islamic ethics because information is increasingly being processed electronically, from storage and retrieval to sharing and usage. The pervasiveness of indecent content, which was once disseminated locally, has become an issue of national and international concern with the development of the Internet [4].

The new media, which is a catch-all term for the Internet, email, blogs, social networking sites like Myspace, Facebook and Twitter, digital TV and mobile phones, is fast becoming a popular global information platform. It is the new form of mass media uniquely mediated by technology, especially the Internet. Unlike the traditional print and electronic media, the new media is interactive and user driven. The users themselves, rather than editors, determine the content. It poses a great threat to new users, especially children, because of the unwanted contents on the net. 
Technology is a double-edged sword. A student can go online for gainful research or spent his or her time on phonographic sites or the "phonosphere" [5]. An attempt to control a student misusing the online facility could easily be repulsed by a claim to rights of privacy. When used appropriately, the new media promotes learning and research. But they could also be misused, often inadvertently by the users resulting in the compromising of their privacy, fraud and even harm to children by pedophiles. Rarely does a student, who posts his photographs, address and other personally identifiable information (PII) on Facebook, think of the invaluable trails he or she is leaving behind for a kidnapper or a fraudster to exploit.

The new media also ruffles the fabrics of a country's social networks. Children are expected to keep company with the aged who would then impart the wisdom of the land to the younger generation. But this may not be possible when the children chat online or text friends. By engaging more with the "strangers without" than the "friends within", the young make the elderly lonely and desperately excluded in the high-tech world.

There are some justified reasons to study IT ethics. The underlying reasons are in the following:

i. Islam forbids all types of unethical activities in every sphere of human life.

ii. Most of the people, including IT professionals, are unfamiliar with the ethical violations of information technology.

iii. Making us behave like responsible professionals in the workstations.

iv. We should study IT ethics which will teach us how to avoid computer abuses and catastrophes.

v. Controlling the access of IT resources for children and motivating them for rational access to IT resources.

vi. IT ethics are vitally important for users to avoid using illegal IT resources permanently and require some ethical issues independently.

\section{Literature Review}

The concept of information ethics, developed in the 1980's, seeks to address the issues of values and traditions, desired or derided by a 
given society. It attempts to create "the standard for judging behavior of an individual or a member of community and classifying these as moral or amoral [5]. Information ethics is a relatively new area of study comprised of several distinct yet interrelated disciplines, including applied ethics, intellectual property, privacy, free speech, and societal control of information [6].

The information technology profession does not currently have such a strong self-regulatory organization, but there are some groups that have developed Codes of Ethics. One of the most widely recognized and publicized is the ACM (Association for Computing Machinery) Code of Ethics and Professional Conduct enacted in 1992. The ACM Code of Ethics is the most comprehensive guideline to bridge the gap between information technology and ethics. Its content is studied in this manuscript. Culture has been found to be more important than codes on influencing behavior [7].

However, it has been found that IT ethics can be successfully taught [8]. Vitell and Davis [9] found that ethics can improve "when top management makes it clear that ethical behavior will be rewarded and unethical behavior will be punished." Hoff [10] suggests that individuals can be trained in ethical decision making in order to make proper ethical decisions. Therefore, exploring the nature of IT ethics and determining both its underlying elements as well as its demographic variability are productive efforts. Understanding these issues can lead to better programs to foster ethical education and improve ethical behavior.

Beginning in 1997, conferences on the Ethics of Electronic Information in the 21st century were held at the University Memphis [11]. The subject of information ethics has also gained international interest as demonstrated by recent activities, starting with the first UNESCO Conference of InfoEthics in 1997 [12]. In 2003, an invitational conference was held in Karlsruhe, Germany under the leadership of the ICIE with support from the Volkswagen-Stiftung [13] in 2004. The World Summit on the Information Society (WSIS 2003) developed the "Declaration of Principles: Building the Information Society: A Global Challenge in the New Millennium," and in February 2007, the First African Conference on Information Ethics was held in South Africa (First African Conference on Information Ethics) [14]. Building on the 2007 conference, in August 2008 a UNESCO and the South African government sponsored 
training workshop on IE and E-Government in Sub-Saharan Africa will be held in South Africa. Over the past nearly 20 years, several schools have incorporated information ethics in their curricula, both as stand-alone courses and as part of other courses, many of which are required core courses.

\section{Ethics \& IT Ethics}

Ethics may be defined as the set of moral principles that distinguish what is right from what is wrong. It is a normative field because it prescribes what one should do or abstain from doing. Ethics are moral standards that guide behavior, actions, and choices. Ethics are grounded in the notion of responsibility (as free moral agents, individuals, organizations, and societies are responsible for the actions that they take) and accountability (individuals, organizations, and society should be held accountable to others for the consequences of their actions). In most societies, a system of laws codifies the most significant ethical standards and provides a mechanism for holding people, organizations, and even governments accountable [15].

IT ethics are not exceptional from the above-mentioned view of ethics. In a world where information technology has come to define how people live and work, and has critically affected culture and values, it is important for us to review ethical issues, as well as social responsibility, in the present world. This is a difficult task because of the diversity in creed, class, caste, dialect, language, culture and race throughout the region. Ethics as reflection on morality is widely accepted among philosopher beginning with Aristotle, the founder of ethics as an academic discipline. As Rafael Capurro, who heads the International Center for Information Ethics (ICIE), reminds us: As a self-referential process ethics is an unending quest on explicit and implicit use of the moral code, that is to say of respect or disrespect, with regard to individual and social communication. In other words, ethic observes the ways we communicate with each other as moral persons and the ways this moral identify is understood [16]. There is, indeed, no unbiased ethical observer [17].

\section{Ethics in Islam}

Islam is the last religion revealed by God (Allah-the almighty) to people. Allah said in the holy Qur'an [20] "This day, I have perfected your religion for you, completed my favor upon you, and have chosen for you Islam as religion” [Quran 5:3]. The holy Qur'an consists of more than 6,000 verses; with hundreds of verses focusing on ethical 
aspects. Islam is basically based on two sources: The Holy Qur'an [20] and Sunnah of Prophet Mohammed (peace be upon him). Sunnah is mainly defined by Muslim scholars as "all what prophet Mohammed says, acts, or agreed on", which is mainly documented in six authenticated resources (Sahih al-bukhari, Sahih Muslim, Sunan AbiDaud, Jamea al-Termethi, Sunan Ibn-Maja, and Sunan al-Nisaae).

The general understanding of ethics in Islam can be express as a "set of moral principles and guidance that recognizes what is right behavior from what is wrong or what one should do or not”. Qur'an and Sunnah, show that all the Muslims' life should be guided by Islamic ethics [21-24]. Allah said "Verily this Qur'an Doth guide to that which is most right (or stable)" [Qur'an 17:9]. Allah uses the term Akhlaq or khuluq in the Holy Qur'an to refer to the ethics. The importance of ethics in Islam is shown when Allah prescribes Prophet Mohammed that he is with great ethics "Prophet of Allah had been raised to a great spiritual dignity” [Qur'an 68:4]. Also Prophet Mohammed said "I was sent to complement the best of ethics". The Qur' an represents the main dimension for the concept of ethics in Islam.

The Islamic ethical system differs from secular ethical systems and from the moral code advocated by other religions. Throughout civilization, these secular models assumed moral codes that were transient and myopic since they were based on the values of their human founders, for example, Epicureanism or happiness for happiness's sake. By contrast, the moral code embedded in Islamic ethics emphasizes the relation of man to his Creator. Because God is perfect and omniscient, Muslims have a code that is neither timebound nor biased by human whims. The Islamic code of ethics is enforceable at all times because the Creator and Monitor is closer to man than his jugular vein, and has perfect, eternal knowledge.

The Qur'an and Sunnah use set of ethical terms to describe the concept of goodness such as: Sidq (Truth), Khayr (Goodness), Birr (Righteousness), Qist (Equity), 'Adl (Equilibrium and Justice), Haqq (Truth and Right), Ma'ruf (Known and approved), Amanah (Honesty), Ikhlas (Sincerity), and Taqwa (Piety). Pious actions are described as Salihat and impious actions are described as Sayyi'at. Some of these terms are repeated in tens (10s) of Qur'anic verses as well as Sunnah. A survey result (term based frequency) for sample of ethical related terms used in Qur'an is shown in the following table. It shows a 
survey result (verse and hadith based frequency) for sample of ethical characteristics used in Qur'an and Authenticated resources of Sunnah.

Table 1

Frequency Of Good Ethical Characteristics In Quran And Sunnah

\begin{tabular}{|l|c|c|}
\hline \multicolumn{1}{|c|}{ Good Ethical Characteristic } & $\begin{array}{c}\text { No of } \\
\text { Verses }\end{array}$ & $\begin{array}{c}\text { No of } \\
\text { Hadith }\end{array}$ \\
\hline Ihsan (beneficence) & 66 & 29 \\
\hline Ikhlas (sincerity) & 23 & 34 \\
\hline Istighfar \& Tawba (forgiveness) & 202 & 100 \\
\hline Amanah, Nazaha, Istiqama (honesty) & 65 & 66 \\
\hline $\begin{array}{l}\text { Iswa Hasana, Irshad Islah (good model \& } \\
\text { Guidance) }\end{array}$ & 67 & 82 \\
\hline $\begin{array}{l}\text { Wafaa Ahd, Ketman Ser (Keep promise and } \\
\text { Secrecy) }\end{array}$ & 31 & 50 \\
\hline $\begin{array}{l}\text { Amr maarof Nahi munkar (order goodness, } \\
\text { prohibiting badness) }\end{array}$ & 13 & 33 \\
\hline Eman \& Taqwa (Believe \& piety) & 595 & 145 \\
\hline $\begin{array}{l}\text { Morality, Husn alkhulug walmuamalah (good } \\
\text { ethics and dealing) }\end{array}$ & 61 & 250 \\
\hline Hikmat \& hulum (wisdom) & 129 & 31 \\
\hline Alhamd, Alshukr, Althanaa (Thankfulness) & 235 & 142 \\
\hline Sabr, Musabara, Kathm ghaidh (patient) & 108 & 64 \\
\hline Adl, Insaf) (fairness) & 23 & 62 \\
\hline Sidq (Truth) & 92 & 44 \\
\hline Rahma, Raafa, Rifq (Merciful) & 227 & 124 \\
\hline Takrem Insan (Mankind priority) & 96 & 24 \\
\hline Ilm, Amal (Science, Work) & 530 & 139 \\
\hline Tafakr, Tadabr, Taaml (thinking) & 83 & 48 \\
\hline
\end{tabular}

These surveys show that Islam supports and rewards people for all goodness and warns, prohibits or punishes people for badness. Islam considers ethics as an essential factor in developing or rebuilding the society based on understanding of the Qur'an and Sunnah. This ethical rebuilding of human behavior will bring benefit, peace, and prosperity to mankind.

\section{Proposed Principles of IT Ethics}

There are many reasons for creating a code of ethics that specifically apply to information technology (IT), including the prevalence of invisibility, inherent anonymity, and the unique malleability (ability to 
be "morphed" into whatever we can imagine) of technology compared to anything in our history.

The Code of Ethics was created to provide principles to guide you in dealing with the complex situations of the information age that eclipse the level of your previous experiences and knowledge. Applying principles requires one to draw on their experience and come up with a fair judgment on how the broad principle may be applied to a specific situation [18]. As an IT professional, there are many ethical and moral values that you must adhere to. You are not only expected to have the highest degree of integrity and honesty, but to act in a responsible and lawful manner when accessing electronic private information. You must assume the custodial obligation to protect data, personal information, and identities from unauthorized access or disclosure, and respect the ownership of information in any form. This requires you -- as an IT professional or organization -- to display a greater amount of self-discipline.

The proposed ethical principles are guidance for IT professionals including end users, especially the Muslims, can be divided into two parts:

\section{A. Islamic principles for IT Ethics:}

This set of principles is for all mankind, including computer and software professionals. Holding to these beliefs and values, you are expected to adhere to the following:

1. Work as vicegerent of Allah: The main objective of creating all mankind by God (Allah) is to warship him; by developing and reconstructing the earth for the best (as vicegerent or Caliph) through their good acting and deeds. Allah said, "I have only created Jinn and Men that they may serve me” [Qur'an 51:56]. "Allah they Lord said to the angels: I will create a vicegerent on earth” [Qur'an 2:30].

2. Performing duty is a warship: Software engineering professionals have to know that, performing their duty is a warship and Allah will reward them for goodness and punish them for badness. Allah said in Qur'an "Then shall anyone who has done an atom's weight of good, see it and anyone who has done an atom's weight of evil, shall see it” [Qur'an 99:7-8]. Prophet in his Hadith said "work is warship".

3. Understand and follow the standard ethics, especially Islamic ethics: IT professionals including end users have to understand 
the standard Islamic ethics (based on Quran and Sunnah). They have to consider it as the highest standard that they should follow in their life and work.

4. Remember the Judgment day: IT professionals including end users have to know that doing goodness and producing useful knowledge will be rewarded by Allah in their life and after death to the Day of Judgment.

5. Management with honesty: IT professional managers and leaders have to subscribe to and promote an ethical approach to the management of software and hardware development and maintenance. They have to show the honesty (Amanah) and equity in performing their duty.

6. Work with highest profession: IT professionals including end users have to advance the integrity and reputation of the profession consistent with the Ummah (nation) interest. They have to do their best using their highest profession.

\section{B. Professional principles for IT Ethics:}

This set of principles is dedicated for all kinds of IT professionals. It is an enhanced version for IEEE/ACM version. It includes:

1. Do no harm: Never intentionally allow harm to come to others as a result of your actions, or inactions.

2. First, seek to understand, then to be understood: Expand your empathic abilities to understand and internalize the affects your actions may have upon others.

3. Fair Representation: Fulfill the promises you make - do as you imply. In essence, people need to be motivated to stop finding excuses, and to take on greater personal and social responsibilities.

4. Do not abuse your privilege of access to private information: IT professionals have unprecedented access to private information requiring a higher level of self discipline.

5. Make every effort to prevent unauthorized disclosure of private information: Ensuring legitimate, authorized access and security of data that has been accessed properly is of paramount concern, and should be taken very seriously. 
6. Utilize available technology to protect private information: Help to advance and make use of technology developed by our peers to provide protection for data, and the medium that transports it. Using technologies such as encryption, Secure Socket Layer, and Pretty Good Privacy are a necessary part of our everyday lives.

7. Strive to improve on the protection of private information: Avoid distributing information that is known to be incomplete, incorrect, inaccurate, or inappropriate. If you know of incorrect private information, or notice data which is not being properly handled or secured, it is your obligation to correct any instances of incorrect, unprotected, or improperly handled private information - or notify someone who can.

8. Do not pass as your own the work of others without proper credit to the author: Regardless of copyright status, it is unacceptable for using the work of others for professional or personal gain without the author, owner, or copyright holder's exclusive permission.

9. Stay abreast of public policy and changes in social theory: Moral values are universally structured by concepts of justice, rights, harm, welfare, and fairness. Expand your own moral reasoning by taking the time to understand these concepts, making a habit of frequent personal reflection to analyse your experiences, and recognise opportunities for improving upon future decisions dealing with moral dilemmas and conflicts.

10. Only access that information which is required to complete your task: It is not necessary to peruse through all available data to complete your job, however, it is up to you to decide what data is needed. With this in mind it is your responsibility to ensure you only use what is needed.

11. Do not attempt to access computers or networks on which you are not authorized: As an IT professional, you realize the importance of computer and network security, therefore attempted access to computers and networks you have no authorization to is viewed as being unethical.

12. Actively educate, and correctly inform those whom are inspired by the populism's of information technology based on ignorance: You must confront those who practice unethical acts 
based on social norms, and inform them of potential harm it does to others, as well as the natural, logical, and legal consequences of doing so. Never attempt to create or increase the dependence of users for the sake of personal gain, such as job security.

13. Do not attempt to gather information for the purpose of identity discovery: There is an unspoken expectation for privacy and protection through anonymity. IT professional's access to multiple databases with private information allows them the ability to discern someone's identity. The only exception to this code will be for legally authorized law enforcement purposes.

14. Foster "voluntary cooperative action of individuals and groups" in complying with the code, because it is key to the success of any Code of Ethics: Individuals and organizations (corporations, institutions, governments, etc) both share the moral and ethical responsibilities of their conduct and activities among each other, to the people affected directly by their actions, and to the general public whom may be affected by those actions in the future.

\section{Challenges and Issues of IT Ethics}

Through information technology, it has now become possible to engage in ethical or unethical business practices electronically any where in the world. For example, should you electronically monitor your employees' work activities and electronic mail? Should you let employees use their work computers for private business or take home copies of software for their personal use? Should you electronically access your employees' personnel records or workstation files? Should we sell customer information extracted from transaction processing systems to other companies? These are a few examples of the types of decisions you will have to make that have a controversial ethical dimension. So let's take a closer look at ethical considerations in business and information technology. Identify ethical issues in how the use of information technologies in organization affects employment, individuality, working conditions, privacy, crime, health, and solutions to societal problems. Some ethical issues are discussed below:

Accessibility: What information does a person or organization have a right or a privilege to obtain, under what conditions, and with what safeguards? Now accessibility is one of the major concerns for practising IT ethics.

Computer Monitoring: One of the most explosive ethical issues concerning the quality of work is computer monitoring. Computer 
monitoring has been criticized as an invasion of the privacy of employees because, in many cases, they do not know that they are being monitored or don't know how the information is being used. Since computer monitoring increases the stress on employees who must work under constant electronic surveillance. In effect, computer monitoring creates an "electronic sweatshop," where workers are forced to work at a hectic pace under poor working conditions.

Computer Matching: Unauthorized use or mistakes in the computer matching of personal data are another controversial threat to privacy. Individuals have been mistakenly arrested and jailed, and people have been denied credit because their physical profiles or Social Security numbers have been used to match them incorrectly or improperly with the wrong individuals. Another threat is the unauthorized matching of computerized information about you extracted from the databases of sales transaction processing systems, and sold to information brokers or other companies.

Computer crime: Computer crime is the threat caused by the criminal or irresponsible actions of computer users who are taking advantage of the widespread use of computer networks in our society. It thus presents a major challenge to the ethical use of IT. Computer crime poses serious threats to the integrity, safety, and quality of most business information systems, and thus makes the development of effective security methods a top priority. Computer crime involves the theft of money, services, software, and data; destruction of data and software, especially by computer viruses; malicious access, or hacking on the Internet or other computer networks, and violations of privacy.

Privacy Issues: IT makes it technically and economically feasible to collect, store, integrate, interchange, and retrieve data and information quickly and easily. This characteristic has an important beneficial effect on the efficiency and effectiveness of computer-based information systems. However, the power of IT to store and retrieve information can have a negative effect on the right to privacy of every individual. For example, confidential E-mail messages by employees are monitored by many companies. Personal information is being collected about individuals every time they visit a site on the World Wide Web. The unauthorized use of such information has seriously damaged the privacy of individuals. Errors in such databases could seriously hurt the credit standing or reputation of an individual. 
Data Alteration or Theft: Making illegal changes or stealing data is another form of computer crime. For example, an employee of the International Islamic University Chittagong was convicted of taking payments from students and using the university's computer system to change their grades in return.

Computer virus: Computer viruses enter a computer system typically through illegal or borrowed copies of software or through network links to other computer systems. Thus, a computer virus or worm can spread destruction among many users. Though they sometimes display only humorous messages, they more often destroy the contents of memory, hard disks, and other storage devices. As a good end user computing practice, we should avoid using software from questionable sources without checking for viruses.

Intellectual property: Unauthorized copying is illegal because software is intellectual property that is protected by copyright law and user licensing agreements. Millions of dollars of software is illegally copied each year all over the world. This phenomenon has a great impact on the software industry in the region. Most importantly, for the sake of growth in indigenous ICT innovation and invention, local software industries in Asia-Pacific need local support in protecting their intellectual property rights and investment.

Pornography: Pornography, which is a moral crime in most societies, has started to attract millions of internet surfers from all over the world, including from the Asia-Pacific region.

Software piracy: Computer programs are valuable property and thus are the subject of theft from computer systems. However, unauthorized copying of software, or software piracy, is also a major form of software theft. Several major cases involving the unauthorized copying of software have been widely reported.

Health Issues: The use of information technology in the workplace raises a variety of health issues. Heavy use of computers is reportedly causing health problems like job stress, damaged arm and neck muscles, eye strain, radiation exposure, and even death by computer caused accidents. For example, computer monitoring is blamed as a major cause of computer-related job stress. 


\section{Recommendations}

1. Takwah (fearness of Allah) must be achieved as the main characteristic of a Muslim so that he/she doesn't deed any offence which harmful for others.

2. Islamic moral values should be practiced in family life thus a child can grow up with Islam from his early life.

3. Tracking softwares can be installed to monitor and to control IT users' daily activities with IT resources.

4. Several types of courses can be introduced based on Islamic ethics from primary to higher education level.

5. Recognition in educational systems that computer literacy is a basic and necessary skill and incorporating the ethical issues in IT related subjects.

6. High levels of awareness of information security and cybercrime issues amongst users at home, in government and educational institutions, in the private sector, and amongst legal officers;

7. Increased exchange of information on information security and cybercrime at the regional and national levels;

8. Policies and legal regulatory frameworks at the national level that are consistent with existing or developing international legal instruments;

9. Effective regional mechanisms for preventing cybercrime and improving protection against, detection of, and responses to, cybercrime; Secure information systems, networks and transactions in the public and private sectors;

10. Safe and secure environments for users, especially children and young persons;

11. Effective mechanisms for detection of, and responses to, cybercrime at the national and regional levels, including the creation of environments that are conducive to the reporting of cybercrime;

12. Widespread adoption of, and compliance with, relevant codes of conduct and best practices at the national level;

13. Promotion of fundamental understanding of the destructive nature of piracy in terms of hindering the following: the progress in the ICT industry, wealth creation, employment 
opportunities, knowledge creation, and national status and reputation;

14. Regulation and control of software prices commensurate with national per capita incomes;

15. Enforcement of penalties for crimes committed against copyright and intellectual property protection laws; and Encouragement of indigenous IT to maintain availability of software products at local affordable price.

\section{Conclusion}

We are living in a networked environment (infosphere) that is becoming increasingly synchronized (time), delocalized (space) and correlated (interactions). Previous revolutions (especially the agricultural and the industrial ones) created macroscopic transformation in our social structures and physical environments, often without much foresight. Now the growth of informational revolution is dramatic. We shall be in deep trouble if we do not take seriously the fact that we are constructing the new environment that will be inhabited by future generations. Although ethical and professional principles for IT users including professionals were adopted by professional organizations and committees such as IEEE, ACM, ABET; but some international survey results show that IT users including professionals still facing many ethical related problems. Islamic sources (Holy Qur'an and Sunnah) provide a high standard of ethics for individual, communities and Ummah (nation) levels. Islamic ethics are stable, comprehensive, fair and standard which are suitable for all nations and times; and when followed leads to create an ethically great society. The paper adopting the main roadmap steps as well as the new principles for IT users, which based on Islamic ethical values. This effort can help in solving many of the current ethical related IT users' problems. It offers a good opportunity for IT users specially Muslims to understand and implement such standard and comprehensive ethical values in their life as well as having their right role in workstations. 


\section{References}

1. M. Abi-Read, “Code or ethics? Which one?” SIGCSE Bulletin, 31(2), 1999, pp.73-77,

2. K. Marshall, (). "Has technology introduced new ethical problems?” Journal of Business Ethics, 1999, pp- 19, 81-90.

3. B. Stead, and J.Gilbert, "Ethical issues in electronic commerce", Journal of Business Ethics, 2001, pp-34, 75-85.

4. H. Keith, "Dirty Discourse: Sex and Indecency in Broadcasting”, 2007, The Online Disinhibition Effect, Volume 7, Number 3, 2004, http://lacomunidad.elpais.com/blogfiles/apuntes-cientificos-desdeelmit/71994_Suler.pdf, accessed 18 ${ }^{\text {th }}$ June, 2011.

5. K. Ahn, "A Study on the Methodology of Information Ethics Education in Youth”, IJCSNS International Journal of Computer Science and Network Security, $\quad$ VOL.6 No.6, 2006. http://paper.ijcsns.org/07_book/200606/200606A15.pdf, accessed $15^{\text {th }}$ June, 2011. P-91.

6. D. Peterson, (2002). "Computer ethics: The influence of guidelines and universal moral beliefs”, Information Technology \& People, 15(4) , pp-346-361.

7. R. Sims, \& J. Brinkmann, "Enron ethics (or culture matters more than codes)", Journal of Business Ethics, 2003, pp- 45, 243-256.

8. J. Couger, Preparing IS students to deal with ethical issues. MIS Quarterly, 1989, 13(2), pp- 211-218.

9. S. Vitell and D. Davis, "Ethical beliefs of MIS professionals: The frequency and opportunity for unethical behaviour”, Journal of Business Ethics, 9, 1990, pp- 63-70.

10. J. Hoff, “Students, ethics, and surveys”, journal of Business Ethics, 8, 1989, pp823-825.

11. V. Hoesle, "The third world as a philosophical problem". Social Research, 1992, pp- 59, 227-263.

12. B. Paterson, "We cannot eat data: The need for computer ethics to address the cultural and ecological impacts of computing”, Idea Group Reference, Hershey, PA, 2007, pp- 153-168.

13. V. Mbarika, F. Payton, L. Kvasny, and A. Amadi, 2007. "IT education and workforce participation: A new era for women in Kenya?", The Information Society, pp- 23, 1, 1-18.

14. L. Kvasny, "Let the sisters speak: Understanding information technology from the standpoint of the 'other'”, The DATA BASE for Advances in Information Systems 2006, pp- 37, 4, 13-25.

15. K. C. Laudon, Traver, C.G. and J.P. Laudon 1996. Information Technology and Society, pp.513. 
IIUC Studies, Vol. 9

16. E. G. Seebauer, Robert L. Barry, "Fundamentals of Ethics for Scientists And Engineers”, Oxford university press, NY, 2001.

17. S. A. Hameed, "Toward Software Engineering Principles based on Islamic Values”, ICCCE08, Malaysia 2008.

18. L. D. Introna, "Privacy and the Computer: Why We Need Privacy in the Information Society," Metaphilosophy, Vol. 28, No. 3, 259-275, 1997. 